\title{
The Effect of Tibialis Anterior Tendon Transfer on Metatarsus Adductus Deformity in Children with Clubfoot
}

\author{
Pes Ekinovarusu Olan Çocuklarda Tibialis Anterior Tendon Transferinin Metatarsus \\ Adduktus Deformitesine Etkisi
}

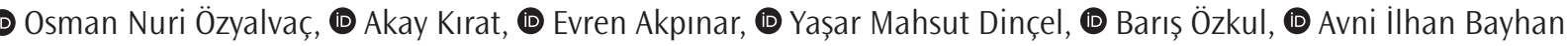
Metin Sabancı Baltalimanı Osteopathic Training and Research Hospital, Clinic of Orthopedics and Traumatology, İstanbul, Turkey

\begin{abstract}
Introduction: Tibialis anterior tendon transfer (TATT) is a common treatment method used in the dynamic supination of the foot due to sequelae or relapse of pes equinovarus (PEV). In this method, the TAT is transferred from its insertion on the medial cuneiform to the lateral cuneiform. Therefore, TATT surgery may have a corrective effect on metatarsus adducus deformity by creating a force vector that pushes the middle of the foot from medial to lateral. However, there is limited literature on the effect of TATT on metatarsus adductus deformity, which is one of the components of clubfoot. The aim of our study was to investigate the effect of TATT on metatarsus adductus deformity.
\end{abstract}

Methods: Sixteen feet of 11 patients who underwent TATT with the diagnosis of PEV between 2007-2015 were included in the study. Pre- and postoperative talus-1.metatarsal angle, talocalcaneal angle and 4. metatars-metaphyseal angle were measured on standing antero-posterior radiographs. The correction rate of metatarsus adductus deformity was statistically analyzed.

Results: After a mean follow-up of $26 \pm 15$ months, the mean talus $-1^{\text {st }}$ metatarsal angle decreased from 18.8 \pm 1 degrees to $10.9 \pm 6$ degrees, the mean talocalcaneal angle from 22.5 degrees \pm 8.6 to $24.4 \pm 9.3$ degrees and the mean $4^{\text {th }}$ metatarsalmetaphyseal angle from $38 \pm 14$ degrees to $27 \pm 11$ degrees after TATT. While there were statistically significant radiological corrections in talus $-1^{\text {st }}$ metatarsal angle and $4^{\text {th }}$ metatarsalmetaphyseal angle $(p<0.05)$, there was no statistically significant change in the talocalcaneal angle $(p=0.51)$.

Conclusion: TATT provides radiological improvement in the metatarsus adductus deformity in children with PEV. The reason for this is that the Tibialis in PEV works as an invertor rather than dorsiflexor/evertor of the ankle. In conclusion, the need for additional surgery for metatarsus adductus deformities in patients undergoing TATT should be reviewed.

Keywords: Clubfoot, metatarsus adductus, pes equinovarus, tibialis anterior tendon transfer

\section{$\ddot{0 Z Z}$}

Amaç: Pes ekinovarus (PEV) sekellerine ve nükslerine bağ|ı ayağın dinamik süpinasyonun tedavisinde tibialis anterior tendon transferi (TATT) oldukça sık uygulanan bir tedavi yöntemidir. Bu yöntemde TAT'nin insersyosu ayak medialinden orta hatta taşınmaktadır. Dolayısı ile tibialis anteior kasının ayak ortasını medialden laterale doğru iterek metatarsus adduktus deformitesini düzeltici yönde etki gösteren bir kuvvet vektörü olușmaktadır. Ancak TATT'nin PEV'in komponentlerinden biri olan metatarsus adduktus deformitesi üzerine olan etkisi hakkında yeterli literatür bilgisi bulunmamaktadır. Çalışmamızın amacı TATT'nin metatarsus adduktus deformitesi üzerine olan etkisini araștırmaktır.

Yöntemler: Kliniğimiz dijital arşivinden faydalanılarak 20072015 yılları arasında PEV tanısı ile TATT yapılan 11 hastanın 16 ayağı çalışmaya dahil edildi. Hastaların basarak çekilmiş olan ayak anteroposterior grafileri üzerinden operasyon öncesi ve sonrası talus-1. metatars açısı, talokalkaneal açı ve 4. metatars metafizyel açı ölçümler yapılararak metatarsus adduktus deformitesinin düzelme miktarı istatiksel olarak değerlendirildi.

Bulgular: Ortalama $26 \pm 15$ aylık takip sonrası tendon transferi cerrahisinden sonra talus-1. metatars açısı 18,8 \pm 1 dereceden $10,9 \pm 6 \quad 18,8 \pm 1$ dereceye, talokalkaneal açı 22,5 $\pm 8,6$

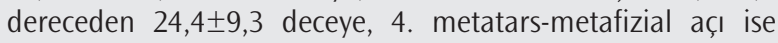
$38 \pm 14$ dereceden $27 \pm 11$ dereceye geriledi. Talus-1. metatars açısı ve 4. metatars-metafizial açıda istatiktiksel olarak anlamlı radyolojik düzeltme gözlemlenirken $(p<0,05)$, talokalkaneal açıda istatistiksel olarak anlamlı değișiklik gözlenmedi $(p=0,51)$.

Sonuç: PEV'li çocuklarda TATT, metatarsus adduktus deformitesinde radyolojik düzelme sağlamaktadır. Bunun nedeni, PEV'de TAT'nin ayakta dorsifleksor/evertor olarak değil invertör olarak çalışmaya başlaması olarak düşünülebilir. Sonuç olarak TATT uygulanan hastalarda metatarsus adduktus deformitesi için ek cerrahi uygulaması gerekliliği yeniden gözden geçirilmelidir.

Anahtar Kelimeler: Çarpık ayak, metatarsus adduktus, pes ekinovarus, tibialis anterior tendon transferi 


\section{Introduction}

Idiopathic clubfoot deformity remains a common pediatric orthopedic problem with an incidence of $1 / 1000$ live birth (1). Successful outcomes can be achieved by serial manipulations and casting following the principles of the Ponseti method. However, relapses can be seen up to $50 \%$ in clubfoot treatment, regardless of initial treatment outcomes and correction achieved (2). Relapse is the result of the same pathology that causes the primary deformity and is usually associated with noncompliance with the Ponseti brace protocol (3). Manipulation and recasting are usually the initial treatments for relapses, but operative treatment may be needed for residual deformities after serial casting (4).

In our study, we hypothesized that by transferring tibialis anterior tendon (TAT) into lateral cuneiform in TAT transfer (TATT) procedure, transforms the supination vector of the TAT to a dorsiflexion vector that may gradually reduce metatarsus adductus deformity in relapsed clubfoot. The purpose of this study was to evaluate the radiologic outcomes and the reducing effects of TATT procedure on metatarsus adductus deformity in relapsed clubfoot.

\section{Methods}

After approval (approval number 08/02/2017-67) from the Institutional Review Board of Metin Sabancı Baltalimanı Osteopathic Hospital, a retrospective review of the operative logs from 2006 to 2015 was undertaken to identify all idiopathic clubfoot patients who underwent TATT procedure with at least one year follow-up. Patients who had additional congenital anomalies, neuromuscular disease, and a history of previous surgery other than percutaneous achillotomy were excluded from the study. Also patients who did not have appropriate radiographs and patients with less than one-year follow-up after surgery were excluded from study. Concomitant procedures as achilles tendon lengthening and plantar fasciotomy were noted. Because of the retrospective study design, no approval form was obtained from the patients.

Sixteen feet of 11 patients ( 2 girls) were identified from the medical records. All patients were initially treated for idiopathic clubfoot deformity with Ponseti method. The decision to perform TATT procedure was based on the clinical findings of dynamic supination gait, which was observed during swing and heel strike phases of gait and accompanying the dynamic heel varus deformity.

All surgeries were performed under general anesthesia and pneumatic tourniquet in supine position by one of the three authors. According to Ponseti and Smoley technique, two incisions were made on dorsal aspect of the foot (2). First incision was made longitudinally along the path of the TAT near its insertion. After dissecting TAT, the tendon was totally detached from its insertion and a Krackow stitch was placed into the distal portion of the tendon. The second incision was made over lateral cuneiform under fluoroscopic guidance. Then the tendon was pulled out and moved to the lateral side of the foot subcutaneously. Thus, the tendon remains under the retinaculum. Under fluoroscopic guidance, a drill hole, which was large enough to accommodate the tendon, was made in the middle of the lateral cuneiform. Krackow stitch was threaded into a straight needle and the needle was passed to the plantar aspect of the foot through the drill hole on lateral cuneiform. After that, needle was passed through a felt pad and then through different holes in a button to secure the tendon on the plantar aspect of the foot. Achilles tendon lengthening was performed if the passive dorsiflexion was less than 10 degrees and plantar fasciotomy was performed if needed. A long leg cast was applied keeping the foot in abduction and dorsiflexion for six weeks. Cast and button was removed after six weeks and no additional therapy or bracing was performed thereafter.

Medical records were reviewed to document the age at surgery, gender and follow-up period. Anteroposterior (AP) weight-bearing radiographs of foot and ankle were evaluated on INFINITT Healthcare Picture Archiving Communication System (INFINITT Healthcare Co., Ltd., Seoul, South Korea) by a board certified orthopedic surgeon (Figure 1). Preoperative AP radiographs of the foot and final follow-up radiographs were evaluated and measurements of talus $-1^{\text {st }}$ metatarsal angle $\left(\mathrm{TM}_{1}\right)$, talocalcaneal angle (TC) and (III) $4^{\text {th }}$ metatarsal - metaphyseal angle $\left(\mathrm{M}_{4} \mathrm{M}\right)$ were made on AP radiographs of foot (Figure 1).

\section{Statistical Analysis}

Statistical analysis was performed using Statistical Package for Social Sciences Software version 17 (SPSS, Inc., Armonk, NY, USA). Normality of the variable distribution was tested with Kolmogorov-Smirnov test. Continuous variables were displayed as means \pm standard deviation. Continuous variables were compared using the paired sample t-test. $p$ values $<0.05$ were considered to be statistically significant.

\section{Results}

Sixteen feet of 11 relapsed clubfoot patients were evaluated. The mean age at the time of surgery was $4.4 \pm 1.1$ years. The mean follow-up time was $26 \pm 15$ months. Measurements of preoperative and final follow up AP radiographs of foot are listed in Table 1.

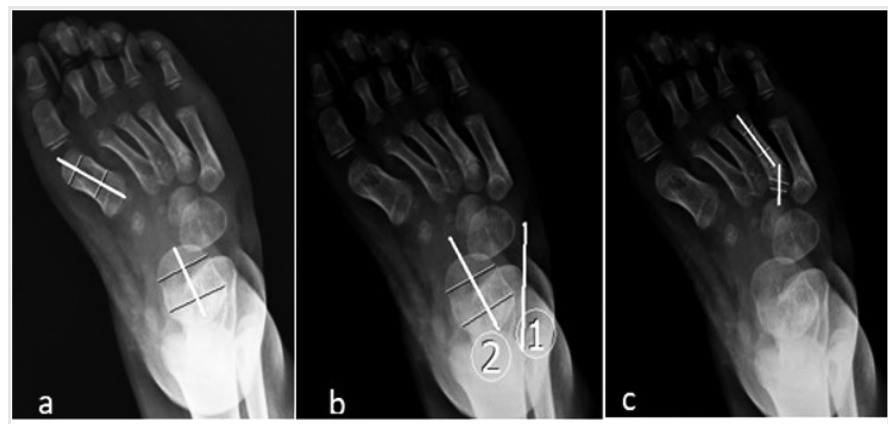

Figure 1. Measurements of (a) talus $-1^{\text {st }}$ metatarsal angle $\left(\mathrm{TM}_{1}\right),(\mathrm{b})$ talocalcaneal angle (TC) and (c) $4^{\text {th }}$ metatarsal - metaphyseal angle $\left(\mathrm{M}_{4} \mathrm{M}\right)$ on $\mathrm{AP}$ radiographs of foot

Table 1. Radiographic measurement results

\begin{tabular}{l|l|l|l|} 
& Preoperative & Final follow-up & $\mathbf{p}$ \\
\hline $\mathrm{TM}_{1}$ angle & $18.8 \pm 1$ & $10.9 \pm 6$ & $0.009^{*}$ \\
\hline $\mathrm{TC}$ angle & $22.5 \pm 8.6$ & $24.4 \pm 9.3$ & 0.512 \\
\hline $\mathrm{M}_{4} \mathrm{M}$ angle & $38 \pm 14$ & $27 \pm 11$ & $0.023^{*}$
\end{tabular}

$T m_{1}$ : talus $-1^{\text {st }}$ metatarsal angle, $m_{4} m: 4^{\text {th }}$ metatarsal - metaphyseal angle 
The mean $\mathrm{TM}_{1}$ angle was decreased from $18.8 \pm 1$ degrees to $10.9 \pm 6$ degrees with statistically significant difference $(p<0.05)$. Also the mean $\mathrm{M}_{4} \mathrm{M}$ angle was decreased from $38 \pm 14$ degrees to $27 \pm 11$ degrees with statistically significant difference $(p<0.05)$. Changes in TC angle were not statistically significant $(p>0.05)$.

\section{Discussion}

The results of the TATT procedure in the treatment of relapsed clubfoot have been investigated in various studies $(2,5,6)$. The TATT procedure primarily improves dynamic supination gait by providing muscle balance (7). As a consequence of transferring TAT into lateral cuneiform, the cuneiforms and the cuboid are shifted more laterally than normal and that corrects and stabilizes relapsing clubfoot (2). In 1940, Garceau first described the TATT procedure in the treatment of relapsed clubfoot and reported good and excellent results in forefoot adduction correction (6). In our study, we also observed the metatarsus adductus reducing effect of TATT procedure on relapsing clubfoot.

The metatarsus adductus is evaluated by the angle between the longitudinal axis of the metatarsus and the navicular, cuboid and cuneiform bones (8). Farsetti et al. (2) presented the results of TATT procedure in relapsing clubfoot by evaluating the changes of the angles formed by the longitudinal of the navicular - the first cuneiform, the calcaneus - the fifth metatarsal, and the calcaneus - the cuboid by plain radiographs and computed tomography scans (2). After analyzing the outcomes, they observed that the foot abduction occurs after TATT procedure. They stated that the changes in angles might be due to the abducting/everting force caused by the transfer that was able to shift the cuneiforms, cuboid, and the whole forefoot more laterally. It is difficult to evaluate metatarsus adductus in the pediatric age due to insufficient ossification centers of the navicular, cuboid and cuneiform bones (8). Therefore, it is recommended to use $\mathrm{TM}_{1}$ angle and $\mathrm{M}_{4} \mathrm{M}$ angle on radiographs to evaluate metatarsus deformity in children $(5,8)$. For this reason, unlike the study of Farsetti et al. (2), we evaluated different radiological measurements assessing the metatarsus adductus deformity in our study. Nevertheless, we observed that metatarsus adductus decreased after the TATT procedure.

In a long-term study that evaluates results of the TATT procedure in the treatment of relapsed clubfoot, Holt et al. (1) observed no differences in $\mathrm{TM}_{1}$ angle with the reference group. Similarly, we observed decrease in $\mathrm{TM}_{1}$ in our study. The changes in $\mathrm{TC}$ angle were not remarkable in our study. In the same study, authors observed a smaller TC angle, but they stated that TC angle noted in patients who had been treated with the TATT procedure resulted in no clinically detectable differences between the groups as demonstrated by similar outcomes measured with questionnaires (1). Therefore, we believe that the absence of significant changes in TC angle will not lead any clinical problems in future.

Kuo et al. (6) reported their outcomes of TATT procedure performed in relapsed clubfoot with an average follow-up time of $10.3( \pm 3.5)$ years (6). They evaluated the forefoot adduction with measurements of TC and $\mathrm{TM}_{1}$ angles performed on the AP radiographs. They observed that the $\mathrm{TM}_{1}$ angle was corrected a mean of 24.2 degrees (6). In our study, we observed that the $\mathrm{TM}_{1}$ was corrected a mean of 7.9 degrees with statistical significance, which was relatively lower than the study of Kuo et al. (6). We think that this difference is due to our relatively short follow-up period, which was about 2 years. We believe that gradual correction of metatarsus adductus deformity will be observed and longterm results of our study will show similar correction rates with previous studies (6).

Metatarsus adductus deformity in relapsed clubfoot are also treated by osteotomies of metatarsal, cuneiform and cuboid bones $(5,9,10)$. But these procedures may have serious complications as delayed wound healing, malunion, nonunion and shortening of the metatarsal (11). Knörr et al. (5) described a percutaneous method of correcting of severe metatarsus deformity in children. They observed 5.83 degrees correction in $\mathrm{M}_{4} \mathrm{M}$, which was stated to be successful. In our study, we observed 11 degrees of correction, which was higher than referral study. Therefore, we think that results of TATT procedure on $M_{4} M$ changes was sufficient to reduce metatarsus adductus deformity. We think that complications related to the osteotomy procedures can be avoided by choosing TATT procedure in the treatment of metatarsus adductus in relapsed clubfoot.

\section{Study Limitations}

Our study has some limitations. Due to retrospective nature of this study, the outcome evaluation was only conducted with radiological measurements. As a limitation of this study, we were not able to provide functional assessment of the TATT. Because of our short-term results, we are unable to report the results of the TATT procedure in skeletal maturity.

\section{Conclusion}

We think that the TATT procedure provides similar results with simpler intervention compared to osteotomy procedures. Considering the complications of osteotomies in the treatment of metatarsus adductus deformity for relapsed clubfoot, we believe that surgeons should reconsider the necessity of osteotomy for metatarsus adductus deformities in patients undergoing TATT surgery.

Ethics Committee Approval: For this study, approval is taken from the Institutional Review Board of Metin Sabancı Baltalimanı Osteopathic Hospital (approval number: 08/02/2017-67).

Informed Consent: Retrospective study.

Peer-review: Externally and internally peer-reviewed.

Author Contributions: Concept - A.I.B., O.N.Ö.; Design - A.I.B., E.A.; Supervision - A.I.B., O.N.Ö.; Data Collection and/or Processing- A.K., E.A.; Literature Search - B.Ö., Y.M.D.; Writing Manuscript A.I.B., O.N.Ö.; Critical Review - B.Ö., Y.M.D.

Conflict of Interest: No conflict of interest was declared by the authors.

Financial Disclosure: The authors declared that this study received no financial support. 


\section{References}

1. Holt JB, Oji DE, Yack HJ, Morcuende JA. Long-term results of tibialis anterior tendon transfer for relapsed idiopathic clubfoot treated with the Ponseti method: a follow-up of thirty-seven to fifty-five years. J Bone Joint Surg Am 2015; 97: 47-55.

2. Farsetti P, Caterini R, Mancini F, Potenza V, Ippolito E. Anterior tibial tendon transfer in relapsing congenital clubfoot: long-term follow-up study of two series treated with a different protocol. J Pediatr Orthop 2006; 26: 83-90.

3. Haft BGF, Walker CG, Grawford HA. Early clubfoot recurrence after use of the Ponseti method in a New Zealand population. J Bone Joint Surg Am 2007; 89: 487-93.

4. Ponseti IV, Smoley EN. The classic: congenital club foot: the results of treatment. 1963. Clin Orthop Relat Res 2009; 467: 1133-45.

5. Knörr J, Soldado F, Pham TT, Torres A, Cahuzac JP, de Gauzy JS. Percutaneous correction of persistent severe metatarsus adductus in children. J Pediatr Orthop 2014; 34: 447-52.
6. Kuo KN, Hennigan SP, Hastings ME. Anterior tibial tendon transfer in residual dynamic clubfoot deformity. J Pediatr Orthop 2001; 21: 35-41.

7. Lampasi M, Bettuzzi C, Palmonari M, Donzelli O. Transfer of the tendon of tibialis anterior in relapsed congenital clubfoot: long-term results in 38 feet. J Bone Joint Surg Br 2010; 92: 277-83.

8. Dawoodi AI, Perera A. Radiological assessment of metatarsus adductus. Foot Ankle Surg 2012; 18: 1-8.

9. Pohl M, Nicol RO. Transcuneiform and opening wedge medial cuneiform osteotomy with closing wedge cuboid osteotomy in relapsed clubfoot. J Pediatr Orthop 2003; 23: 70-3.

10. Napiontek M, Kotwicki T, Tomaszewski M. Opening wedge osteotomy of the medial cuneiform before age 4 years in the treatment of forefoot adduction. J Pediatr Orthop 2003; 23: 65-9.

11. Steytler JC, Van der Walt ID. Correction of resistant adduction of the forefoot in congenital club-foot and congenital metatarsus varus by metatarsal osteotomy. Br J Surg 1966; 53: 558-60. 